\title{
Enzymes of the Calvin Cycle and Intermediary Metabolism in the Cyanobacterium Anacystis nidulans Grown in Chemostat Culture
}

\author{
By AMALIA D. KARAGOUNI AND J. HOWARD SLATER \\ Department of Environmental Sciences, University of Warwick, \\ Coventry CV4 $7 A L$
}

(Received 31 January 1979)

\begin{abstract}
The cyanobacterium Anacystis nidulans grown in light-limited and $\mathrm{CO}_{2}$-limited chemostat cultures showed varying rates of $\mathrm{CO}_{2}$ fixation with peaks at dilution rates of $0 \cdot 10$ to $0 \cdot 12$ $\mathrm{h}^{-1}$. The specific activities of a number of enzymes of the reductive and oxidative pentose phosphate and glycolytic pathways and the tricarboxylic acid and glyoxylate cycles varied significantly as a function of the growth environment (substrate limitation) and organism growth rate. Ribulose-1,5-bisphosphate carboxylase varied 15-fold under $\mathrm{CO}_{2}$-limited conditions but did not change under light-limited conditions. With the exception of phosphoribulokinase, all enzymes which showed a change in specific activity increased with decreasing dilution rate. The specific activities of glucose-6-phosphate dehydrogenase, 6-phosphogluconate dehydrogenase, hexokinase, ribulose-1,5-bisphosphate carboxylase and malate dehydrogenase were significantly higher in organisms grown under $\mathrm{CO}_{2}$-limited conditions than under light-limited conditions. Fructose-1,6-bisphosphate aldolase and phosphoribulokinase specific activities were similar at all growth rates and under both limitations. Isocitrate lyase was the only enzyme examined which showed higher specific activities under light-limited conditions. Thus Anacystis nidulans can selectively express different enzymes, possibly by transcriptional control.
\end{abstract}

\section{INTRODUCTION}

A number of previous investigations have shown that in obligately phototrophic cyanobacteria many of the enzymes involved in intermediary carbon metabolism were hardly affected by the composition of the growth environment (Pearce \& Carr, 1969; Pelroy et al., 1972; Carr, 1973). This has resulted in the suggestion that the inability to control enzyme activity at the transcriptional level is a characteristic feature of obligate autotrophic physiology (Carr, 1973). In particular, the presence or absence of organic compounds has little effect on the specific activities of enzymes of intermediary metabolism (Pearce \& Carr, 1967; Pearce et al., 1969) or amino acid biosynthesis (Hood \& Carr, 1971, 1972; Weber \& Böck, 1968; Delaney et al., 1973). Furthermore, even facultatively phototrophic cyanobacteria such as Aphanocapsa strain 6714 and Chlorogloea fritschii showed only minor alteration in the specific activities of enzymes involved in sugar and carboxylic acid metabolism (Joset-Espardellier et al., 1978). Conversely, other enzyme systems of cyanobacteria are clearly subject to regulation in response to specific environmental conditions. For example, Anacystis nidulans showed a 10- to 15-fold increase in alkaline phosphatase specific activity once the phosphate concentration was reduced to growth-limiting levels (Ihlenfeldt \& Gibson, 1975). Similarly Bone (1971 $a, b)$ showed that growth conditions and specific growth rate affected the specific activities of alkaline phosphatase and nitrogenase in Anabaena flos-aquae grown in continuous culture.

Continuous-flow culture techniques have been extensively used to examine the influence of growth environment and growth rate on enzyme activity in heterotrophic organisms 
(Hamlin et al., 1967; Clarke \& Lilly, 1969; Dean, 1972), particularly the balance between induction and catabolite repression. Typically, much wider ranges of enzyme specific activity may be observed in various chemostat cultures compared with the activities determined in batch culture. This paper examines the influences of $\mathrm{CO}_{2}$-limited and light-limited growth and growth rate on selected enzymes of the reductive pentose phosphate cycle, the oxidative pentose phosphate pathway, the Embden-Meyerhof pathway, and the tricarboxylic acid and glyoxylate cycles in Anacystis nidulans.

\section{METHODS}

Organism and growth. Anacystis nidulans, strain number 625 Indiana University Culture Collection, was obtained from N. G. Carr (University of Liverpool). Stock cultures were maintained as described by Pearce \& Carr (1967). The light- and $\mathrm{CO}_{2}$-limited chemostats were the same as previously described (Slater, 1975; Karagouni \& Slater, 1978).

$\mathrm{CO}_{2}$ assimilation. $\mathrm{CO}_{2}$ fixation was measured as previously described (Slater \& Morris, 1973; Slater, 1975).

Enzyme assays. Organisms were harvested from steady-state cultures by centrifuging at $23000 \mathrm{~g}$ for $15 \mathrm{~min}$ at $4{ }^{\circ} \mathrm{C}$ and washed pellets were resuspended in approximately $10 \mathrm{ml}$ ice-cold $20 \mathrm{~mm}$-Tris/ $\mathrm{HCl}$ buffer $\mathrm{pH}$ 7.5. The organisms were disrupted by two passages through a French pressure cell at $83 \mathrm{MPa}$ at $4{ }^{\circ} \mathrm{C}$. The remaining intact organisms and cell debris were removed by centrifuging at $38000 \mathrm{~g}$ for $45 \mathrm{~min}$ at $4{ }^{\circ} \mathrm{C}$ and the extracts were used immediately for enzyme assays. Cell breakage was estimated by determining the cell numbers before and after disruption. Protein was estimated by the Lowry method using bovine serum albumin as the standard.

Ribulose-1,5-bisphosphate carboxylase [3-phospho-D-glycerate carboxy-lyase (dimerizing); EC 4.1.1.39] was assayed in a mixture containing, in $1.2 \mathrm{ml}: 200 \mu \mathrm{mol}$ Tris $/ \mathrm{HCl}$ buffer $\mathrm{pH} 7 \cdot 8 ; 10 \mu \mathrm{mol} \mathrm{MgCl} 2 ; 5 \mu \mathrm{mol}$ reduced glutathione; $25 \mu \mathrm{mol} \mathrm{NaH}{ }^{14} \mathrm{CO}_{3}$ (specific activity $0.8 \mu \mathrm{Ci} \mu \mathrm{mol}^{-1}$ ); $3 \mu \mathrm{mol}$ ribulose 1,5 -bisphosphate (used to start the reaction); and crude extract (up to $2 \mathrm{mg}$ protein). Samples ( $0.1 \mathrm{ml}$ ) were taken at intervals over $20 \mathrm{~min}$ and added to $0.2 \mathrm{ml}$ ethanol/glacial acetic acid $(95: 5, \mathrm{v} / \mathrm{v})$ in a scintillation vial, to terminate the reaction. After evaporating to dryness the fixed ${ }^{14} \mathrm{C}$ was determined in a liquid scintillation counter. Ribulose1,5-bisphosphate carboxylase specific activity was expressed as $\mu \mathrm{mol} \mathrm{C \textrm {C } _ { 2 }}$ fixed h$^{-1}$ (mg protein) ${ }^{-1}$ or $\mu \mathrm{mol}$ $\mathrm{CO}_{2}$ fixed h${ }^{-1}\left(10^{8} \text { organisms }\right)^{-1}$.

Phosphoribulokinase [ATP:D-ribulose-5-phosphate 1-phosphotransferase; EC 2.7.1.19] was measured as described by Joint et al. (1972). The assay mixture contained, in $1.3 \mathrm{ml}: 200 \mu \mathrm{mol}$ Tris/HCl buffer $\mathrm{pH}$ $8.3 ; 20 \mu \mathrm{mol} \mathrm{MgCl}{ }_{2} ; 1 \mu \mathrm{mol}$ ATP; $75 \mu \mathrm{mol} \mathrm{NaH}{ }^{14} \mathrm{CO}_{3}$ (specific activity $0.8 \mu \mathrm{Ci} \mu \mathrm{mol}^{-1}$ ); $1 \mu \mathrm{g}$ purified spinach ribulose-1,5-bisphosphate carboxylase; $6 \mu \mathrm{mol}$ ribulose 5-phosphate (used to start the reaction); and crude extract (up to $2 \mathrm{mg}$ protein). Sampling, subsequent procedures and expression of enzyme specific activity were the same as for the ribulose-1,5-bisphosphate carboxylase.

6-Phosphogluconate dehydrogenase [6-phospho-D-gluconate: NADP+ 2-oxidoreductase (decarboxylating); EC 1.1.1.44] was assayed by the procedure of $\mathrm{Ng} \&$ Dawes (1973). The assay mixture in silica glass cuvettes contained, in $1.0 \mathrm{ml}: 36 \mu \mathrm{mol}$ Tris/ $\mathrm{HCl}$ buffer $\mathrm{pH} 9.0 ; 1 \mu \mathrm{mol} \mathrm{NADP}+12.5 \mu \mathrm{mol} \mathrm{MgCl}_{2} ; 1.5 \mu \mathrm{mol} 6-$ phosphogluconate (used to start the reaction); and crude extract (up to $0.3 \mathrm{mg}$ protein). 6-Phosphogluconate was omitted from the reference cuvette, and the change in $A_{340}$ was measured. The absorption coefficient for NADH and NADPH was taken as $6.22 \times 10^{3} \mathrm{l} \mathrm{mol}^{-1} \mathrm{~cm}^{-1}$. 6-Phosphogluconate dehydrogenase activity was expressed as nmol substrate converted $\min ^{-1}(\mathrm{mg} \text { protein })^{-1}$ or nmol substrate converted $\min ^{-1}\left(10^{8}\right.$

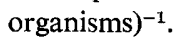

Glucose-6-phosphate dehydrogenase [D-glucose-6-phosphate:NADP+ 1-oxidoreductase; EC 1.1.1.49] was assayed by the method of $\mathrm{Ng} \&$ Dawes (1973). The assay mixture in silica glass cuvettes contained, in $1.0 \mathrm{ml}: 36 \mu \mathrm{mol}$ Tris $/ \mathrm{HCl}$ buffer $\mathrm{pH} 9.0 ; 1.5 \mu \mathrm{mol} \mathrm{NADP}+; 12.5 \mu \mathrm{mol} \mathrm{MgCl}_{2} ; 6 \mu \mathrm{mol}$ glucose 6-phosphate (used to start the reaction); and crude extract (up to $0.3 \mathrm{mg}$ protein). Glucose 6-phosphate was omitted from the reference cuvette, and the subsequent procedures and expression of results were the same as for 6-phosphogluconate dehydrogenase.

Hexokinase [ATP:D-hexose 6-phosphotransferase; EC 2.7.1.1] was assayed by the method of $\mathrm{Ng}$ \& Dawes (1973). The assay mixture in silica glass cuvettes contained, in $1.0 \mathrm{ml}: 36 \mu \mathrm{mol}$ Tris/ $\mathrm{HCl}$ buffer $\mathrm{pH}$ 9.0; $12.5 \mu \mathrm{mol} \mathrm{MgCl}_{2} ; 10.8 \mu \mathrm{mol} \mathrm{ATP} ; 2 \mu \mathrm{mol} \mathrm{NADP}+; 0.75$ units yeast glucose-6-phosphate dehydrogenase; $100 \mu \mathrm{mol} \mathrm{D}$-glucose (used to start the reaction); and crude extract (up to $0.3 \mathrm{mg}$ protein). The remaining procedures were as for 6-phosphogluconate dehydrogenase.

Fructose-1,6-bisphosphate aldolase [D-fructose-1,6-bisphosphate D-glyceraldehyde-3-phosphate-lyase; EC 4.1.2.13] was measured as described by Tabita \& Lundgren (1971). The reaction mixture contained, 


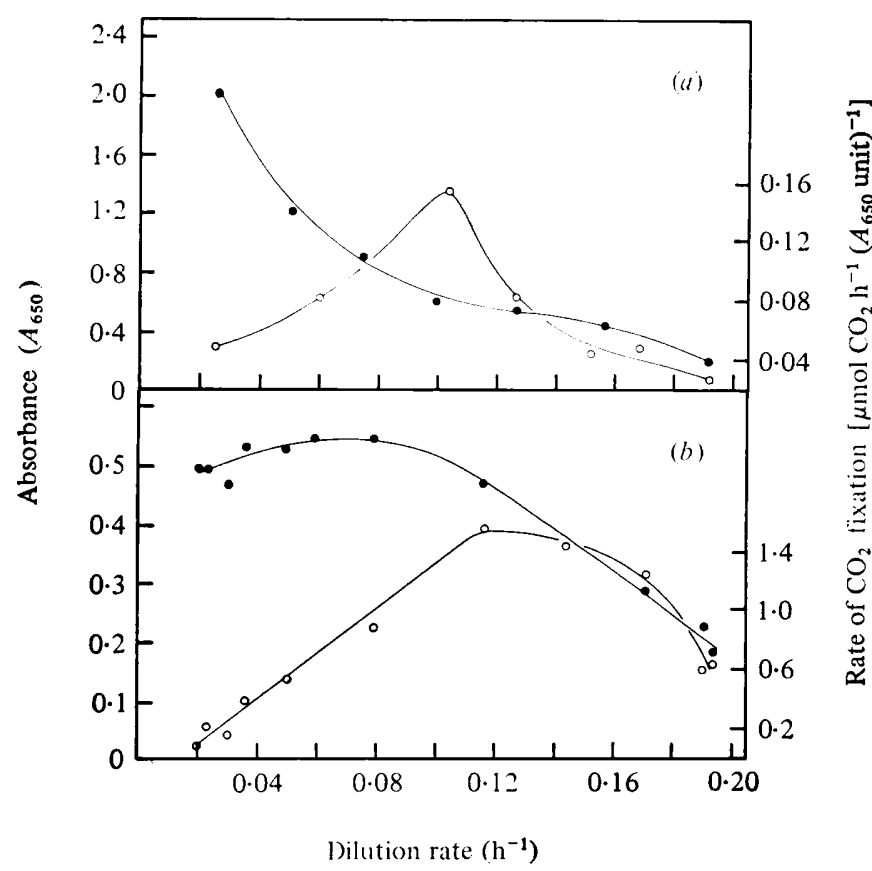

Fig. 1. Influence of dilution rate on the steady-state biomass concentration $\left(A_{650}\right)(\Theta)$ and rate of $\mathrm{CO}_{2}$ photoassimilation $(O)$ for light-limited $(a)$ and $\mathrm{CO}_{2}$-limited $(b)$ chemostat cultures.

in $1.0 \mathrm{ml}: 100 \mu \mathrm{mol}$ Tris $/ \mathrm{HCl}$ buffer $\mathrm{pH} 8.5 ; 1.25 \mu \mathrm{mol}$ fructose 1,6 -bisphosphate; $10 \mathrm{mg} \alpha$-glycerophosphate dehydrogenase from rabbit muscle; $0.2 \mu \mathrm{mol} \mathrm{NADH}$; and crude extract (up to $0.4 \mathrm{mg}$ protein) (used to start the reaction). The remaining procedures were as for 6-phosphogluconate dehydrogenase.

Isocitrate lyase [ $\mathrm{L}_{\mathrm{s}}$-isocitrate glyoxylate-lyase; EC 4.1.3.1] was assayed according to Pearce \& Carr (1967). The reaction mixture contained, in $1.0 \mathrm{ml}: 50 \mu \mathrm{mol}$ Tris $/ \mathrm{HCl}$ buffer $\mathrm{pH} 6.8 ; 4 \mu \mathrm{mol} \mathrm{MgCl}{ }_{2} ; 16 \mu \mathrm{mol}$ phenylhydrazine; $4 \mu \mathrm{mol}$ cysteine; $6 \mu \mathrm{mol}$ DL-isocitrate; and crude extract (up to $0.3 \mathrm{mg}$ protein) (used to start the reaction). Enzyme activity was measured by the change in $A_{340}$ and was expressed as nmol substrate converted $\min ^{-1}$ (mg protein) $)^{-1}$ or nmol substrate converted $\min ^{-1}\left(10^{8} \text { organisms }\right)^{-1}$.

Malate dehydrogenase [L-malate:NAD ${ }^{+}$oxidoreductase; EC 1.1.1.37] was determined as described by Mehler et al. (1948). The assay mixture contained, in $1.0 \mathrm{ml}: 36 \mu \mathrm{mol}$ Tris $/ \mathrm{HCl}$ buffer pH $6.8 ; 2.5 \mu \mathrm{mol}$ $\mathrm{NAD}^{+} ; 1.5 \mu \mathrm{mol}$ oxaloacetate; and crude extract (up to $0.3 \mathrm{mg}$ protein) (used to start the reaction). $\mathrm{NAD}^{+}$ was omitted from the reference cuvette and the enzyme specific activity was expressed as nmol substrate converted $\mathrm{min}^{-1}$ (mg protein) $)^{-1}$ or nmol substrate converted $\min ^{-1}\left(10^{8} \text { organisms }\right)^{-1}$.

Chemicals. Sugars and other growth medium components were from $\mathrm{BDH}$ and Fisons; sugar phosphates, 6-phosphogluconate, $\mathrm{NAD}^{+}, \mathrm{NADH}, \mathrm{NADP}^{+}$and all assay enzymes from Sigma; ATP from Boehringer; DL-isocitrate and oxaloacetate from Calbiochem; $\mathrm{NaH}^{14} \mathrm{CO}_{3}$ from The Radiochemical Centre, Amersham.

\section{RESULTS}

$\mathrm{CO}_{2}$ fixation and the activity of selected enzymes were examined in steady-state cultures grown under either light-limited or $\mathrm{CO}_{2}$ (bicarbonate)-limited conditions over a range of dilution rates from $0 \cdot 02$ to $0 \cdot 19 \mathrm{~h}^{-1}$. Changing the dilution rate resulted in different patterns of steady-state biomass concentrations for the two limitations (Fig. $1 a, b$ ). Under $\mathrm{CO}_{2}$ limited conditions, the culture biomass, measured in terms of absorbance, dry weight or cell number, showed the normal nutrient-limited chemostat pattern with the culture density remaining relatively constant at dilution rates up to $0 \cdot 10 \mathrm{~h}^{-1}$, thereafter declining as the dilution rate was increased towards the critical dilution rate (Fig. 1b). Under light-limited conditions, the biomass continued to increase significantly with decreasing dilution rate. Over the range of dilution rates tested, light was the only growth-limiting factor. The patterns 


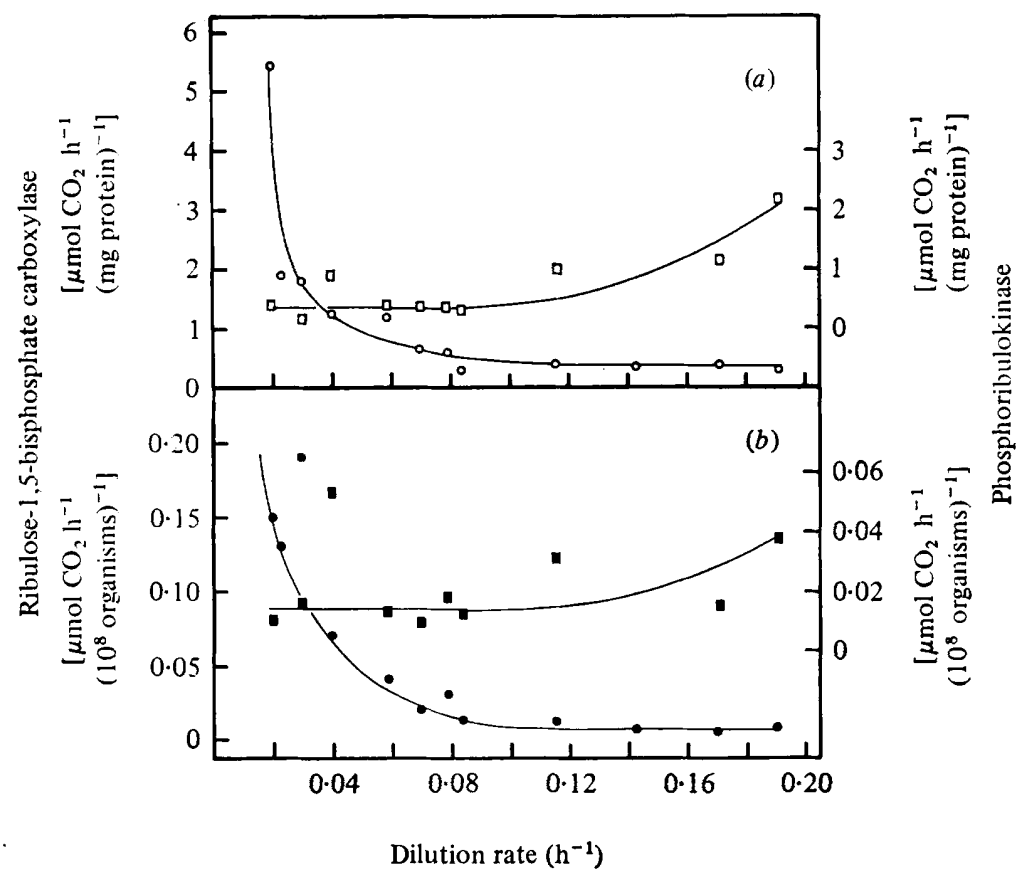

Fig. 2. Influence of dilution rate on the steady-state activities of ribulose-1,5-bisphosphate carboxylase $(O, \odot)$ and phosphoribulokinase $(\square, \square)$ in $\mathrm{CO}_{2}$-limited cultures: activities are expressed per unit protein $(a)$ and per unit cell number $(b)$.

of $\mathrm{CO}_{2}$ fixation, measured in intact organisms under optimal experimental conditions, were similar, showing peaks of assimilation at dilution rates between $0 \cdot 10$ and $0 \cdot 12 \mathrm{~h}^{-1}$ (Fig. $1 \mathrm{a}$, $b$ ), although the rate of $\mathrm{CO}_{2}$ fixation was significantly greater in organisms grown under $\mathrm{CO}_{2}-$ limited conditions than in those grown under light-limited conditions.

A number of different patterns of changing enzyme specific activity with dilution rate were observed in the cultures grown under the two different limitations. In $\mathrm{CO}_{2}$-limited cultures, ribulose-1,5-bisphosphate carboxylase specific activity, both in terms of activity per unit protein or per unit cell number, increased 15 -fold with decreasing dilution rate (Fig. 2). The specific activity was constant at dilution rates $(D)$ above $0 \cdot 10 \mathrm{~h}^{-1}$ [lowest activity $0.40 \mu \mathrm{mol} \mathrm{CO} \mathrm{CO}_{2}$ fixed $\mathrm{h}^{-1}$ (mg protein) ${ }^{-1}$ ] and only increased when the dilution rate was below $0 \cdot 10 \mathrm{~h}^{-1}$. Under light-limited conditions, ribulose-1,5-bisphosphate carboxylase specific activity remained constant at all dilution rates tested at $0.45 \mu \mathrm{mol} \mathrm{CO}_{2}$ fixed $\mathrm{h}^{-1}$ (mg protein $)^{-1}$, i.e. similar to the lowest specific activity in high dilution rate $\mathrm{CO}_{2}$-limited cultures. The specific activity in terms of unit cell number was also constant over the dilution rate range examined under light-limited conditions.

A second reductive pentose phosphate cycle enzyme, phosphoribulokinase, showed a different pattern with a slight increase in activity in organisms grown at higher dilution rates in $\mathrm{CO}_{2}$-limited cultures (Fig. 2).

The two initial enzymes of the oxidative pentose phosphate pathway, 6-phosphogluconate dehydrogenase and glucose-6-phosphate dehydrogenase, increased in specific activity by factors of 2 to 4 with decreasing dilution rate (Fig. $3 a, b$ ), although the small changes in glucose-6-phosphate dehydrogenase activity in light-limited organisms may not be significant. The minimum specific activities of glucose-6-phosphate dehydrogenase, i.e. those observed at high dilution rates, were similar under both limitations [5 to $6 \mathrm{nmol}$ substrate converted $\min ^{-1}$ (mg protein) $)^{-1}$; the maximum activity was considerably higher in $\mathrm{CO}_{2^{-}}$ limited cultures than in light-limited cultures at the same dilution rate. Although 6-phospho- 


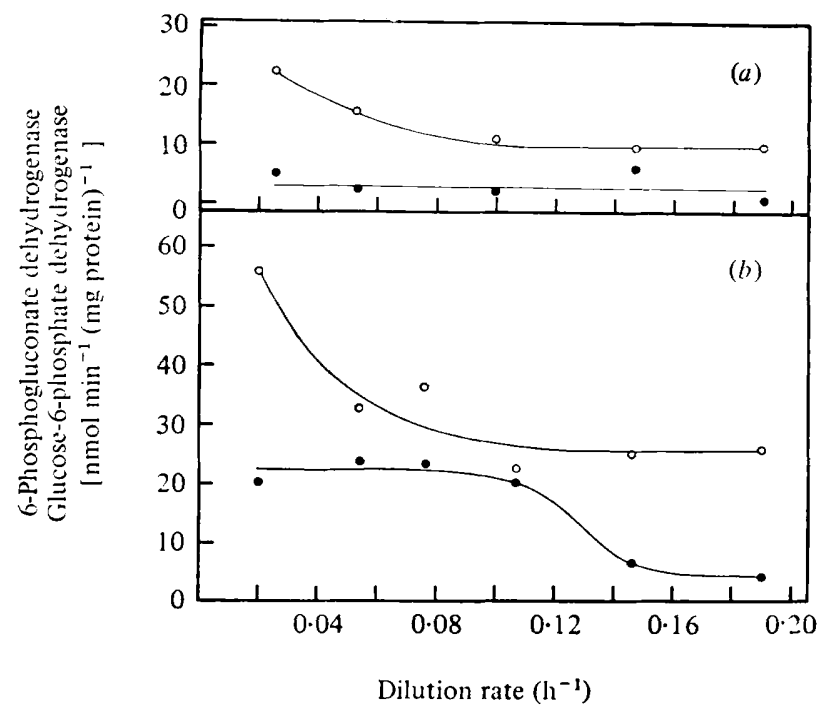

Fig. 3. Influence of dilution rate on the steady-state activities of 6-phosphogluconate dehydrogenase $(\mathrm{O})$ and glucose-6-phosphate dehydrogenase $(O)$ in light-limited $(a)$ and $\mathrm{CO}_{2}$-limited $(b)$ chemostat cultures.

gluconate dehydrogenase activity increased approximately 2 -fold in both light- and $\mathrm{CO}_{2}$ limited cultures with decreasing dilution rate, the minimum activity in $\mathrm{CO}_{2}$-limited cultures [25 nmol substrate converted min $^{-1}\left(\mathrm{mg}^{2} \text { protein }\right)^{-1}$ ] was 2.5 times greater than the lowest activity in light-limited cultures [10 nmol substrate converted $\left.\min ^{-1}(\mathrm{mg} \text { protein })^{-1}\right]$. The changes in enzyme activities in relation to unit number of organisms were identical to the changes in specific activities expressed on the basis of total protein.

Similarly, the activity of hexokinase, a representative enzyme of the glycolytic pathway, showed the same pattern whether the specific activities were calculated on the basis of unit cell number or unit total protein. The hexokinase activity increased 3-fold with decreasing dilution rate in light-limited cultures (Fig. $4 a$ ) whereas the activity in organisms grown under $\mathrm{CO}_{2}$-limitation showed a sharp increase below $D=0 \cdot 10 \mathrm{~h}^{-1}$, representing a 4 -fold increase, with a peak of activity at approximately $D=0.05 \mathrm{~h}^{-1}$ (Fig. $4 b$ ). As in the case of 6-phosphogluconate dehydrogenase, the minimum activity observed under $\mathrm{CO}_{2}$-limited conditions was considerably greater than that under light-limited conditions. Indeed, the maximum specific activity under light-limited conditions $\left[24 \mathrm{nmol}\right.$ substrate converted $\mathrm{min}^{-1}(\mathrm{mg}$ protein $)^{-1}$ ] was the same as the minimum activity in organisms grown at a high dilution rate under $\mathrm{CO}_{2}$-limited conditions.

Fructose-1,6-bisphosphate aldolase, which functions in both the reductive pentose phosphate cycle and the glycolytic pathway, had specific activities which did not vary with dilution rate and, moreover, showed similar levels [7 to $8 \mathrm{nmol}$ substrate converted $\mathrm{min}^{-1}$ (mg protein $\left.)^{-1}\right]$ whether the organisms were grown under light- or $\mathrm{CO}_{2}$-limited conditions (Fig. $4 a, b$ ).

Malate dehydrogenase specific activities were approximately 2- to 3-fold higher in organisms grown under $\mathrm{CO}_{2}$-limited conditions than in those grown under light-limited conditions (Table 1) although the pattern of changing activities as a function of dilution rate was not regular. Isocitrate lyase was the only enzyme examined which generally showed considerably higher activities in light-limited organisms [average value of $74 \mathrm{nmol}$ substrate converted $\mathrm{min}^{-1}(\mathrm{mg} \text { protein })^{-1}$ ] than in $\mathrm{CO}_{2}$-limited organisms [average value of $12 \mathrm{nmol}$ substrate converted $\min ^{-1}(\mathrm{mg} \text { protein })^{-1}$ for $D \geqslant 0.05 \mathrm{~h}^{-1}$ ]. The high isocitrate lyase activity at $D=0.02 \mathrm{~h}^{-1}$ was the average result of four separate steady-state cultures all of which 


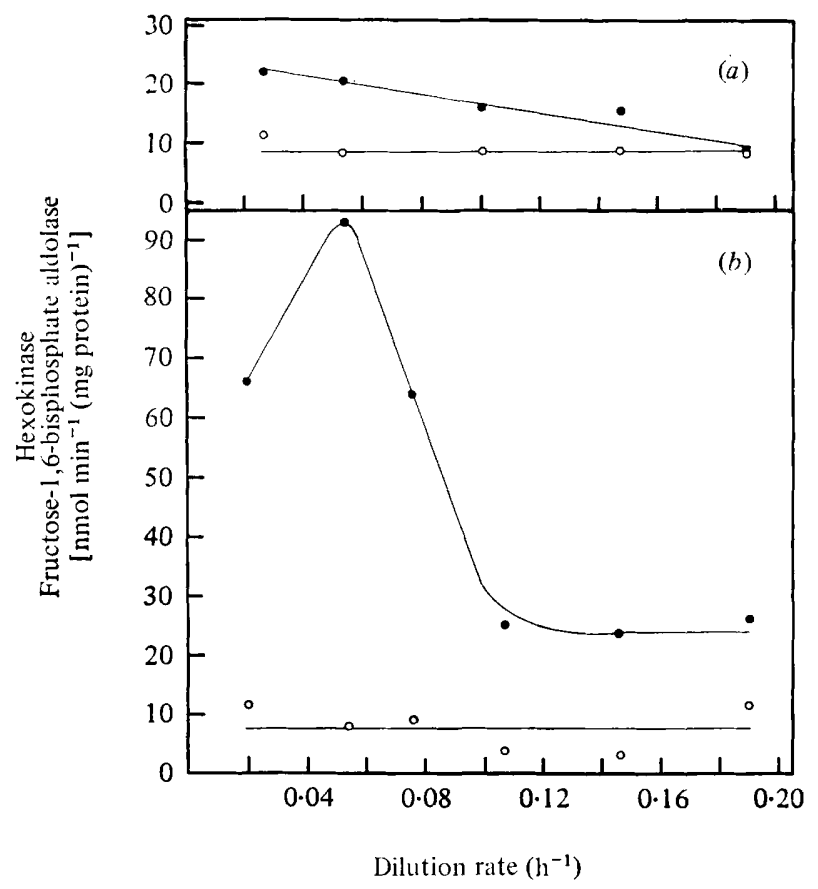

Fig. 4. Influence of dilution rate on the steady-state activities of fructose-1,6-bisphosphate aldolase $(O)$ and hexokinase $(O)$ in light-limited $(a)$ and $\mathrm{CO}_{2}$-limited $(b)$ chemostat cultures.

\section{Table 1. Changes in specific activities of malate dehydrogenase and isocitrate lyase in response to dilution rate and growth limitation}

Enzyme activities are expressed as nmol substrate converted $\min ^{-1}(\mathrm{mg} \text { protein })^{-1}$.

\begin{tabular}{|c|c|c|c|c|c|c|c|c|c|c|c|}
\hline \multirow[b]{3}{*}{ Enzyme } & \multicolumn{5}{|c|}{ Light-limited chemostat } & \multicolumn{6}{|c|}{$\mathrm{CO}_{2}$-limited chemostat } \\
\hline & \multicolumn{5}{|c|}{ Dilution rate $\left(\mathrm{h}^{-1}\right)$} & \multicolumn{6}{|c|}{ Dilution rate $\left(\mathrm{h}^{-1}\right)$} \\
\hline & 0.03 & 0.05 & $0 \cdot 10$ & $0 \cdot 15$ & 0.19 & 0.02 & 0.05 & $0 \cdot 08$ & $0 \cdot 11$ & $0 \cdot 15$ & $0 \cdot 19$ \\
\hline $\begin{array}{l}\text { Ialate dehydrogenase } \\
\text { ocitrate lyase }\end{array}$ & $\begin{array}{r}1 \cdot 0 \\
77 \cdot 5\end{array}$ & $\begin{array}{r}1 \cdot 4 \\
83 \cdot 0\end{array}$ & $\begin{array}{r}3 \cdot 2 \\
90 \cdot 1\end{array}$ & $\begin{array}{r}5 \cdot 7 \\
54 \cdot 0\end{array}$ & $\begin{array}{r}2 \cdot 8 \\
63 \cdot 7\end{array}$ & $\begin{array}{r}14 \cdot 7 \\
110 \cdot 0\end{array}$ & $\begin{array}{l}9 \cdot 3 \\
6 \cdot 7\end{array}$ & $\begin{array}{r}7 \cdot 8 \\
23 \cdot 5\end{array}$ & $\begin{array}{l}9.5 \\
8.2\end{array}$ & $\begin{array}{r}6 \cdot 7 \\
10 \cdot 1\end{array}$ & $\begin{array}{r}6 \cdot 7 \\
14 \cdot 5\end{array}$ \\
\hline
\end{tabular}

showed significantly greater activities at this dilution rate compared with other steadystate cultures (Table 1).

\section{DISCUSSION}

Our study has shown that a number of enzymes involved in intermediary metabolism in the cyanobacterium Anacystis nidulans were present at significantly different specific activities under appropriate growth conditions. The variations between different enzymes showed that the changes in specific activities were not associated with a general phenomenon, such as an alteration in the total protein content of the organism, since such changes might have been expected to alter all the activities in a similar fashion. Furthermore, in some cases the same enzyme behaved differently between light-limited and $\mathrm{CO}_{2}$-limited growth conditions indicating that differences in environmental conditions, in contrast to changes in the organisms' specific growth rate only, were important in the expression of enzyme activity. These results suggest that $A$. nidulans could selectively express different enzymes at the transcriptional level, although we cannot exclude completely the possibility of regulation 
at the translational level or control of enzyme levels due to activation or rates of enzyme turnover.

In one case, the change in specific activity was similar to those reported for enzymes known to be under transcriptional control (Bone, 1971 $a, b$; Ihlenfeldt \& Gibson, 1975). Ribulose1,5-bisphosphate carboxylase showed a wide range of activities under growth conditions where it might be expected to show such changes; that is, it increased in specific activity in organisms grown in environments where growth was limited by the availability of one of the enzyme's substrates, namely $\mathrm{CO}_{2}$ (bicarbonate). The rate of $\mathrm{CO}_{2}$ assimilation depended on the concentration of this substrate and hence in environments with low $\mathrm{CO}_{2}$ concentrations an increase in the activity of ribulose-1,5-bisphosphate carboxylase would increase the rate of fixation. The kinetics of conventional nutrient-limited chemostat culture predicts that the $\mathrm{CO}_{2}$ concentration would decrease with decreasing dilution rate and so account for the greater ribulose-1,5-bisphosphate carboxylase specific activity with decreasing dilution rate. The higher the ribulose-1,5-bisphosphate carboxylase activities, the greater the capacity to scavenge for and assimilate low, growth-limiting concentrations of the sole carbon source. The principle of elevated activities of an initial enzyme involved in the metabolism of a growth-limiting nutrient is well established (Dean, 1972); for example, heterotrophic bacteria have a higher $\beta$-galactosidase activity when growing on lactose as the limiting nutrient (Horiuchi et al., 1962). However, ribulose-1,5-bisphosphate carboxylase (and also the other enzymes examined) did not show the wide range of activities exhibited by the catabolic enzymes of heterotrophic bacteria (for example, see Clarke \& Lilly, 1969). From our results, it seems that the alteration in the activity of ribulose-1,5-bisphosphate carboxylase was in response to changes in the external $\mathrm{CO}_{2}$ concentration and not different growth rates, since under light-limited conditions with $\mathrm{CO}_{2}$ in excess, at all the dilution rates examined there was no change in the specific activity.

The ribulose-1,5-bisphosphate carboxylase activity in vitro accounted for only $10 \%$ of the in vivo rate of $\mathrm{CO}_{2}$ assimilation required for the growth of the organisms at high dilution rates and reflects the problems of correlating enzyme activity with the behaviour of the intact organisms. However, in neither light-limited nor $\mathrm{CO}_{2}$-limited cultures did the changing pattern of $\mathrm{CO}_{2}$ fixation by intact organisms correlate with the observed ribulose1,5-bisphosphate carboxylase activities. This suggests that other factors than ribulose-1,5bisphosphate carboxylase activities influenced the $\mathrm{CO}_{2}$ fixation rate by intact organisms. For example, the influence of other carboxylases, such as phosphoenolpyruvate carboxylase (Colman et al., 1976), have not been examined in this context.

The capacity of $A$. nidulans to alter enzyme specific activities with respect to changing growth rate was limited since, apart from ribulose-1,5-bisphosphate carboxylase, the enzymes with variable activities showed only 2- to 4-fold changes over the growth rate range examined. Moreover, three of the enzymes under $\mathrm{CO}_{2}$-limited conditions and six under lightlimited conditions showed no changes, substantiating the concept of little transcriptional control (Carr, 1973). With the exception of fructose-1,6-bisphosphate aldolase, phosphoribulokinase and isocitrate lyase, all the enzymes examined showed considerably higher specific activities in organisms grown under $\mathrm{CO}_{2}$-limited conditions compared with lightlimited conditions. Under $\mathrm{CO}_{2}$-limited conditions the intracellular concentration of carbon compounds would be expected to be lower than under conditions of excess $\mathrm{CO}_{2}$, a situation likely to result in the derepression of enzymes involved in carbon metabolism. However, the maximum differences were only 4-fold, again suggesting a limited capacity to alter enzyme levels in response to different growth environments. It is interesting that the changes observed occurred for those enzymes at the beginning of different pathways and which may be involved in the regulation of carbon flow in the pathway. Whether or not the transcription of initial enzymes is regulated more efficiently than other pathways remains to be determined by a comprehensive analysis of all the central metabolic pathway enzymes. 


\section{REFERENCES}

Bone, D. H. (1971a). Relationship between phosphates and alkaline phosphatase of Anabaena flos-aquae in continuous culture. Archiv für Mikrobiologie 80, 147-153.

BoNe, D. H. (1971b). Nitrogenase activity and nitrogen assimilation in Anabaena flos-aquae growing in continuous culture. Archiv für Mikrobiologie 80, 234-241.

CARR, N. G. (1973). Metabolic control and autotrophic physiology. In The Biology of BlueGreen Algae, pp. 39-65. Edited by N. G. Carr \& B. A. Whitton. Oxford: Blackwells Scientific.

Clarke, P. H. \& LiLly, M. D. (1969). The regulation of enzyme synthesis during growth. Symposia of the Society for General Microbiology 19, 113. 159.

Colman, B., Cheng, K. H. \& Ingle, R. K. (1976). Relative activities of PEP carboxylase and RuDP carboxylase in blue-green algae. Plant Science Letters 6, 123-127.

DEAN, A. C. R. (1972). Influence of environment on the control of enzyme synthesis. Journal of Applied Chemistry and Biotechnology 22, 245259.

Delaney, S. F., Dickson, A. \& Carr, N. G. (1973). The control of homoserine- $O$-transsuccinylase in a methionine-requiring mutant of the bluegreen alga Anacystis nidulans. Journal of General Microbiology 79, 89-94.

Hamlin, B. T., NG, F. M-W. \& Dawes, E. A. (1967). Regulation of enzymes of glucose metabolism in Pseudomonas aeruginosa by citrate. In Microbial Physiology and Continuous Culture, pp. 211-231. Edited by E. O. Powell, C. G. T. Evans, R. E. Strange \& D. W. Tempest. London: HMSO.

Hood, W. \& CARr, N. G. (1971). Apparent lack of control by repression of arginine metabolism in blue-green algae. Journal of Bacteriology 107, 365-367.

HOOD, W. \& CARR, N. G. (1972). Branched-chain amino acid biosynthesis in the blue-green alga Anabaena variabilis. Journal of General Microbiology 73, 417-426.

Horiuchi, T., Tomizawa, T. \& Novick, A. (1962). Isolation and properties of bacteria capable of high rate of $\beta$-galactosidase synthesis. Biochimica et biophysica acta 55, 152-163.

Ihlenfeldt, M. J. A. \& Gibson, J. (1975). Phosphate utilisation and alkaline phosphatase activity in Anacystis nidulans (Synechococcus). Archives of Microbiology 102, 23-28.

Joint, I. R., Morris, I. \& Fuller, R. C. (1972). Purification of a complex of alkaline fructose 1,6-bisphosphatase and phosphoribulokinase from Rhodospirillum rubrum. Journal of Biological Chemistry 247, 4833-4838.

Joset-Espardellier, F., Astier, C., Evans, E. H. \& CARR, N. G. (1978). Cyanobacteria grown under photoautotrophic, photoheterotrophic and heterotrophic regimes: sugar metabolism and carbon dioxide fixation. FEMS Microbiology Letters 4, 261-264.

Karagouni, A. D. \& Slater, J. H. (1978). Growth of the blue-green alga Anacystis nidulans during washout from light- and carbon dioxide-limited chemostats. FEMS Microbiology Letters 4, 295-299.

Mehler, A. H., Kornberg, A., Grisolia, S. \& OCHOA, S. (1948). The enzymatic mechanism of oxidation-reductions between malate or isocitrate and pyruvate. Journal of Biological Chemistry 174, 961-977.

NG, F. M-W. \& Dawes, E. A. (1973). Chemostat studies on the regulation of glucose metabolism in Pseudomonas aeruginosa by citrate. Biochemical Journal 132, 129-140.

Pearce, J. \& Carr, N. G. (1967). The metabolism of acetate by the blue-green algae, Anabaena variabilis and Anacystis nidulans. Journal of General Microbiology 49, 301-313.

Pearce, J. \& CarR, N. G. (1969). The incorporation and metabolism of glucose by Anabaena variabilis. Journal of General Microbiology 54, 451-462.

Pearce, J., Leach, C. K. \& Carr, N. G. (1969). The incomplete tricarboxylic acid cycle in the blue-green alga Anabaena variabilis. Journal of General Microbiology 55, 371-378.

Pelroy, R. A., Rippka, R. \& Stanier, R. Y. (1972). Metabolism of glucose by unicellular blue-green algae. Archiv für Mikrobiologie 87, 303-322.

SlATER, J. H. (1975). The control of carbon dioxide assimilation and ribulose 1,5-diphosphate carboxylase activity in Anacystis nidulans grown in a light-limited chemostat. Archives of Microbiology 103, 45-49.

Slater, J. H. \& Morris, I. (1973). Photosynthetic carbon dioxide assimilation by Rhodospirillum rubrum. Archiv für Mikrobiologie 88, 213-223.

TABITA, R. \& Lundgren, D. G. (1971). Heterotrophic metabolism of the chemolithotroph Thiobacillus ferrooxidans. Journal of Bacteriology 108, 334-342.

Weber, H. L. \& Böck, A. (1968). Comparative studies on the regulation of DHDP synthetase activity in blue-green and green algae. Archiv für Mikrobiologie 61, 159-168. 